\title{
Golgi Positioning
}

\author{
Smita Yadav and Adam D. Linstedt \\ Department of Biological Sciences, Carnegie Mellon University, Pittsburgh, Pennsylvania 15213 \\ Correspondence: linstedt@andrew.cmu.edu
}

The Golgi apparatus in mammalian cells is positioned near the centrosome-based microtubule-organizing center (Fig. 1). Secretory cargo moves inward in membrane carriers for delivery to Golgi membranes in which it is processed and packaged for transport outward to the plasma membrane. Cytoplasmic dynein motor proteins (herein termed dynein) primarily mediate inward cargo carrier movement and Golgi positioning. These motors move along microtubules toward microtubule minus-ends embedded in centrosomes. Centripetal motility is controlled by a host of regulators whose precise functions remain to be determined. Significantly, a specific Golgi receptor for dynein has not been identified. This has impaired progress toward elucidation of membrane-motor-microtubule attachment in the periphery and, after inward movement, recycling of the motor for another round. Pericentrosomal positioning of the Golgi apparatus is dynamic. It is regulated during critical cellular processes such as mitosis, differentiation, cell polarization, and cell migration. Positioning is also important as it aligns the Golgi along an axis of cell polarity. In certain cell types, this promotes secretion directed to the proximal plasma membrane domain thereby maintaining specializations critical for diverse processes including wound healing, immunological synapse formation, and axon determination.

\section{MECHANISM OF GOLGI POSITIONING}

$\mathrm{N}$ ewly synthesized proteins and lipids of the secretory pathway are packaged into membrane carriers that bud from the endoplasmic reticulum (ER). These membranes fuse with each other and/or preexisting ER-Golgi intermediate compartment membranes (ERGIC) and are ultimately transported along microtubules toward the centrosome by the dynein motor protein complex. There are two noteworthy models regarding the next step. By the cisternal progression model, the membranes generate new cis-Golgi cisternae as they near the centrosome because of fusion with recycling vesicles bearing cis-Golgi components including processing enzymes. By the stable compartments model, the membranes fuse with preexisting cis-Golgi cisternae thereby delivering their content for processing. By either model, the continuous inward movement of membrane carriers will contribute to the steady state localization of Golgi membranes near the centrosome principally because the membranes bear active dynein at the time of their delivery. In addition, dynein is likely recruited directly from the cytoplasm onto Golgi membranes further contributing to Golgi pericentrosomal positioning. This section covers mechanistic details of dynein-based Golgi

Editors: Graham Warren and James Rothman

Additional Perspectives on The Golgi available at www.cshperspectives.org

Copyright (C) 2011 Cold Spring Harbor Laboratory Press; all rights reserved; doi: 10.1101/cshperspect.a005322

Cite this article as Cold Spring Harb Perspect Biol 2011;3:a005322 
S. Yadav and A.D. Linstedt

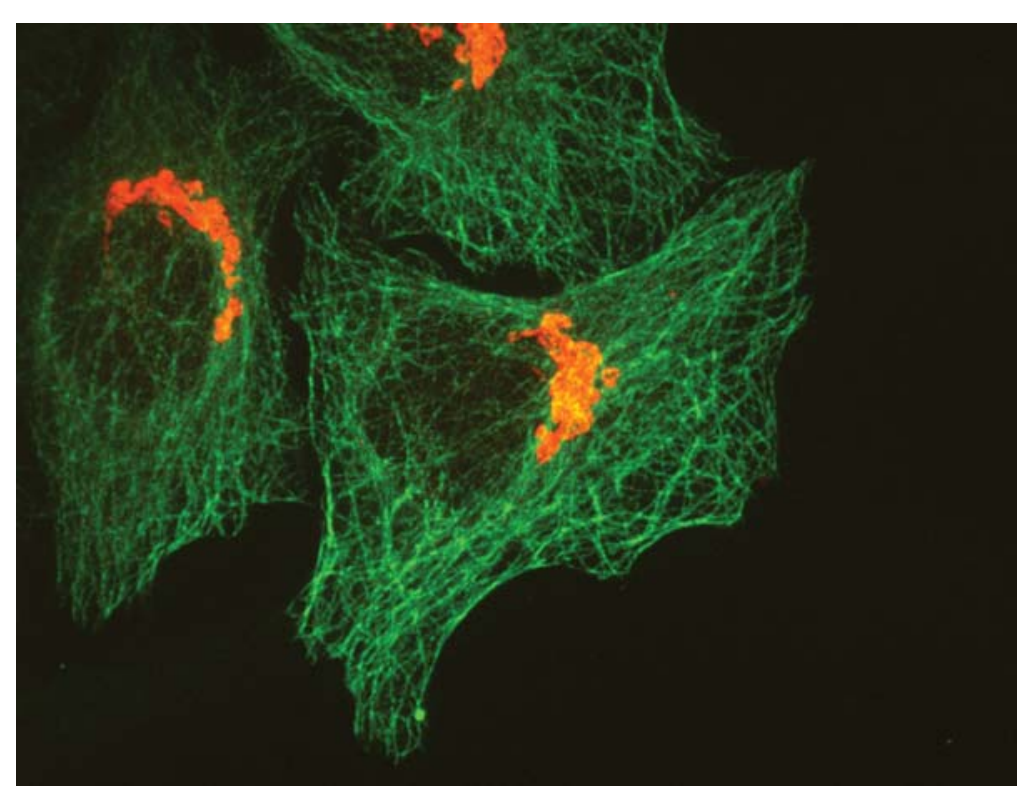

Figure 1. The mammalian pericentrosomal Golgi ribbon. Fluorescent micrograph of cultured HeLa cells stained using antibodies against tubulin (green) and the Golgi marker protein giantin (red) shows relative positions of extensive microtubule network and the Golgi membrane network.

membrane movement (1.1) and also supporting roles in Golgi positioning of: anchoring connections between Golgi membranes and centrosomes (1.2), Golgi-nucleated microtubules (1.3), and bidirectional motility (1.4).

\section{Moving in: Membrane Capture by Motors and Loading onto Microtubules}

Motor proteins use the cytoskeleton network as highways for all membrane transport activities. Centripetal membrane movement is driven by forces generated mainly by the minus-end directed motor protein cytoplasmic dynein, a member of the Dynein superfamily (Schroer et al. 1989; Kardon and Vale 2009). Dynein moves along microtubules carrying bound cargo, such as Golgi membranes, using conformational changes driven by a cycle of ATP binding, hydrolysis and release. Dynein is a multimeric protein complex composed of catalytic heavy chains and noncatalytic intermediate, intermediate light, and light chains (Fig. 2A). Dynein heavy chain (DHC) exists in three isoforms. One of these isoforms, DHC1, assembles to form the dynein-1 motor complex, which is the major mediator of microtubule dependent minus-end directed movement in mammalian cells (Vaisberg et al. 1996). Inhibition of dynein-1 causes the Golgi apparatus to fragment into stacks that are dispersed and immotile, suggesting that continuous dynein driven membrane transport is essential for centrosomal localization of the Golgi apparatus. DHC1 localizes both to Golgi membranes and those of the intermediate compartment (Roghi and Allan 1999) and cultured cells from DHC1 knockout mice have a fragmented Golgi apparatus (Harada et al. 1998). This is further strengthened by RNAi studies in which knockdown of components of the dynein-1 motor cause loss of Golgi positioning (Palmer et al. 2009). There is conflicting data about the role in Golgi positioning of dynein-2, which contains the DHC2 isoform. DHC2 is localized primarily to Golgi membranes and its inhibition by isoform specific antibodies causes loss of Golgi positioning (Vaisberg et al. 1996). However, siRNA mediated depletion of DHC2 fails to show any Golgi phenotype or loss of ER-Golgi 


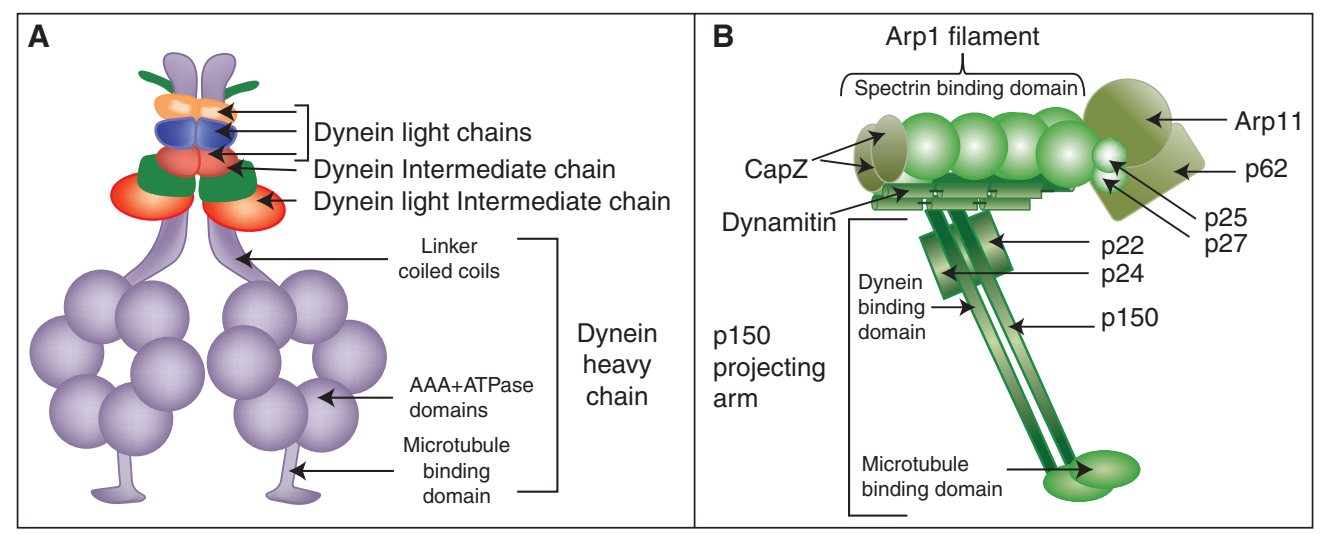

Figure 2. Dynein and dynactin schematic diagrams. The dynein motor protein complex is assembled on two catalytic heavy chains each containing a microtubule-binding domain, a motor domain consisting of six AAA ATPase modules, and a coiled-coil linker region $(A)$. The linker region binds to intermediate chains and light intermediate chains and the assembled intermediate chains bind light chains. The multisubunit dynactin complex has a projecting arm comprised of dimeric p150 that binds dynein intermediate chains and microtubules and a rod-shaped core comprised of an Arp1 filament that can bind spectrin on membranes $(B)$.

transport (Palmer et al. 2009). Indeed, other studies show a role for DHC2 in primary cilia biogenesis (Pazour et al. 1999). Although dynein-1 is the primary motor implicated in Golgi positioning, a minus-end directed member of the kinesin motor family, KIFC-3, can also contribute, at least under the condition of cholesterol depletion. Adrenocortical cells cultured from Kifc3-/- mice show a fragmented Golgi and absence of inward Golgi motility but only after cholesterol depletion (Xu et al. 2002). Whether dynein somehow depends on cholesterol for its activity remains to be tested.

Each dynein molecule contains dimerized heavy chains. The carboxyl terminal region of each heavy chain comprises the motor domain and contains six triple-A ATPase domains and a microtubule binding stalk region. The amino terminal region acts as a scaffold that, in the dimer, binds two dynein intermediate chains (DIC) and two light intermediate chains (DLIC) (King et al. 2002). Light chains LC-7 (roadblock), LC-8, and Tctex-1 can form homo- or hetero-dimers and assemble directly on DIC (Nikulina et al. 2004; Kardon and Vale 2009). Although the dynein heavy chain containing the ATPase domains at its carboxyl terminus is sufficient for imparting motility in in-vitro conditions, the assembly of the noncatalytic subunits at the amino terminus is required to mediate specific cargo-adaptormotor linkages that couple motor movement to cargo movement on microtubules. For example, Tctex-1 binds the integral membrane protein rhodopsin to mediate transport of rhodopsin-bearing vesicles in photoreceptor cells (Tai et al. 1999). Tctex-1 is also important for Golgi positioning because siRNA depletion of Tctex-1 blocks ER-Golgi traffic and fragments the Golgi apparatus. Indeed, all of the core subunits appear to comprise a functional unit for Golgi positioning as individual suppression by siRNA of DHC1, DIC-2, LIC1, Tctex-1, Roadblock, and LC-8 blocks ER-to-Golgi traffic and fragments the Golgi (Palmer et al. 2009).

DIC not only acts as a scaffold for assembly of the light chain subunits of dynein but it also links the motor protein to dynactin a large regulatory complex (Vaughan and Vallee 1995). Remarkably, dynactin consists of 11 different polypeptides that assemble forming two morphologically distinct domains: the actin related protein 1 (Arp1) rod and the p150 projecting-arm (Fig. 2B). In actin-like fashion, Arp1 assembles into a $40 \mathrm{~nm}$ filament and this associates with six other subunits forming the central rod-shape of dynactin. Near one end of the Arp1 rod, the carboxyl terminus of the 
elongated p150 subunit binds forming the projecting-arm onto which, at its amino terminus, are bound two other subunits, p50 (dynamitin) and p24 (Schroer 2004). The Arp1 rod is thought to mediate interaction of dynactin with membranes because Arp1 is known to interact with $\beta 3$-spectrin, which is a peripheral membrane protein (Holleran et al. 2001). At its amino terminus, p150 has a microtubule-binding motif, the cytoskeleton-associated protein glycine-rich (Cap-Gly) motif (WatermanStorer et al. 1995). P150 also interacts with microtubule plus tip proteins EB-1 and Clip170 (Askham et al. 2002) and binds to DIC (King et al. 2002). Therefore, via its Arp1 domain, dynactin binds membranes rich in spectrin and via the p150 arm; it connects the motor to microtubules. These interactions are sufficient for motility in vitro as spectrin-coated liposomes move on microtubules in the presence of the purified dynein-dynactin complex (Muresan et al. 2001). Although it is clear that dynactin is involved in dynein-based motility there are several schools of thought regarding its exact role. These are: it confers dynein localization to microtubule plus tips (Vaughan et al. 2002; Watson and Stephens 2006), it activates dynein motor activity (King and Schroer 2000), it tethers dynein to microtubules to promote motor processivity (Waterman-Storer et al. 1995), it is an adaptor linking cargo to dynein (Holleran et al. 2001; Muresan et al. 2001), and it regulates bidirectional movement of membranes (Deacon et al. 2003). Significantly, loss of dynactin from Golgi membranes in Arp1 mutant Drosophila larvae or siRNA depleted cultured cells does not inhibit motor attachment to membranes but does inhibit both plus- and minus-end membrane motility (Haghnia et al. 2007). Further investigation is required to clearly decipher the role dynactin plays in carrier motility and its bidirectional regulation.

RZZ (Rod-ZW10-Zwilch) is another complex that binds DIC and is implicated in Golgi positioning; however, its binding to DIC via ZW10 occurs primarily in mitosis for the purpose of spindle assembly, whereas its role in membrane motility probably involves interaction with the dynactin subunit dynamitin (Starr et al. 1998). During interphase, ZW10 is ER associated (Hirose et al. 2004) through the peripheral ER protein RINT-1 that binds the ER SNARE protein syntaxin-18 (Arasaki et al. 2006). Interestingly, the ZW10 amino-terminal domain binds RINT-1 and dynamitin in a mutually exclusive manner (Inoue et al. 2008). This could be the basis of cycling between ER and Golgi membranes. In any case, dominant negative, knockdown, and antibody inhibition experiments all show loss of Golgi positioning and decreased minus-end Golgi motility (Varma et al. 2006).

Initiation of inward movement of ERderived transport carriers by dynein can occur through direct recruitment of dynein from the cytosol (Fig. 3A), through binding of dynein preloaded on plus-end tips of microtubules to membranes (Fig. 3B), or through delivery of dynein via recycling vesicles (Fig. 3C). These modes are not necessarily exclusive. Blocking preloading by knockdown of EB1, which is required for dynactin association with the plus tips of microtubules, has no apparent effect on ER to Golgi motility suggesting that although preloading takes place it is not required (Watson and Stephens 2006). Recycling of dynein from the Golgi to the ERGIC on membranes has not been observed but it is an interesting possibility suggested by the general finding that membranes show bidirectional motility. In contrast to the other modes, recycling would place a premium on regulating motor activity as opposed to motor recruitment.

In principle, recruitment on membranes can occur by direct binding of the motor to membrane lipids, binding of the motor to peripheral components that bind lipids, or binding to a compartment-specific protein receptor. Direct membrane binding is observed in proteasetreated synaptic membranes (Lacey and Haimo 1994). Synthetic acidic phospholipid vesicles bind dynein and binding increases dynein ATPase activity (Ferro and Collins 1995), but the physiological relevance of direct lipid binding by the motor remains unclear. Changes in lipid composition seem unlikely to account for the specificity of dynein membrane interactions. 


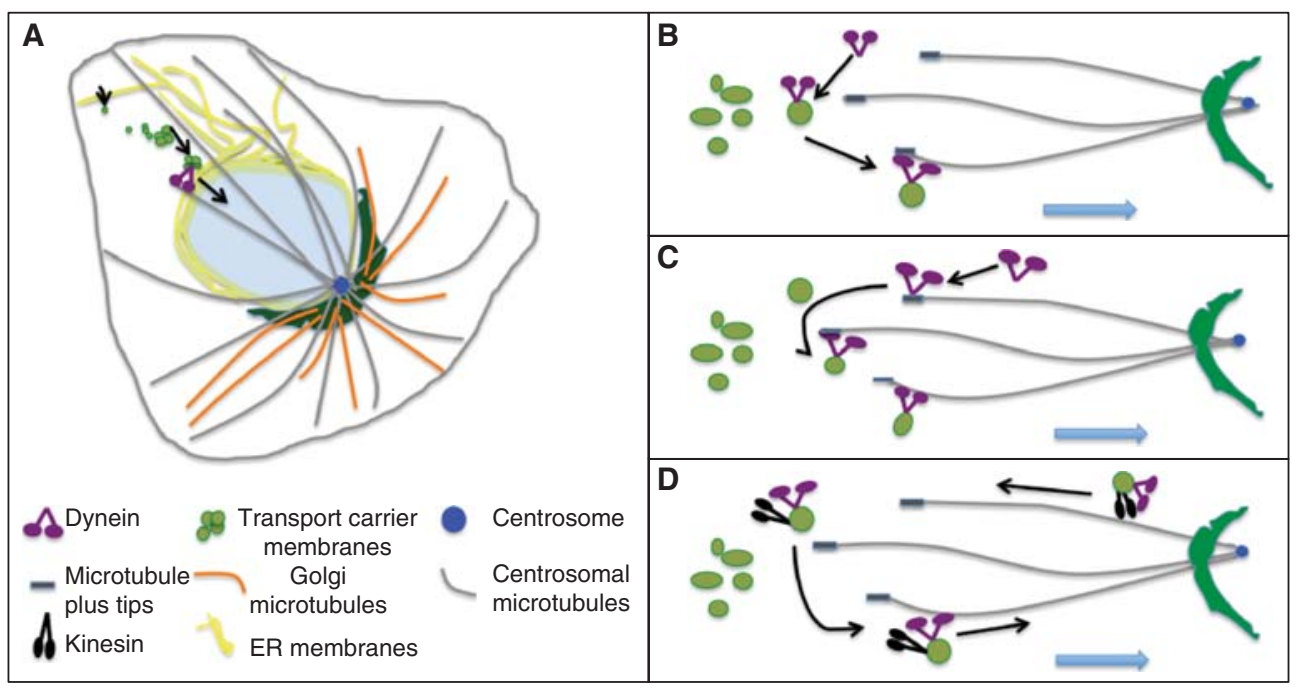

Figure 3. Inward membrane movement. A pericentrosomal Golgi ribbon network is depicted $(A)$. Minus-ends of microtubules converge at the centrosome and support inward movement by dynein of secretory and Golgi membranes derived from the ER. Also shown are three modes of initiating membrane motility. The motor can be recruited directly from the cytosol onto membranes, which then load onto a microtubule $(B)$. The motor can be preloaded on microtubule plus tips, which then probe the cytoplasm and capture membranes $(C)$. The motor can be carried to the cell periphery via recycling vesicles bearing active kinesin and then, on fusion with ERGIC membranes, becomes activated for inward motility $(D)$.

Further, motility of these vesicles is poor and is markedly improved by cytosol addition suggesting the participation of additional factors (Muresan et al. 2001). A key cytosolic component may be $\beta$-spectrin acting to bind lipids and recruit the motor (Fig. 4A). $\beta$-spectrin binds both acidic phospholipids and dynactin and is sufficient to substitute for cytosol in conferring full motility in vitro (Muresan et al.
2001). However, $\beta$-spectrin is localized to many types of membranes again raising the question of how specificity of motor recruitment is obtained (De Matteis and Morrow 2000). A more specifically localized candidate is the peripheral COPII vesicle coat complex component sec 23 , which interacts directly with the p150 subunit of dynactin (Watson et al. 2005). The sec $23 /$ motor connection also

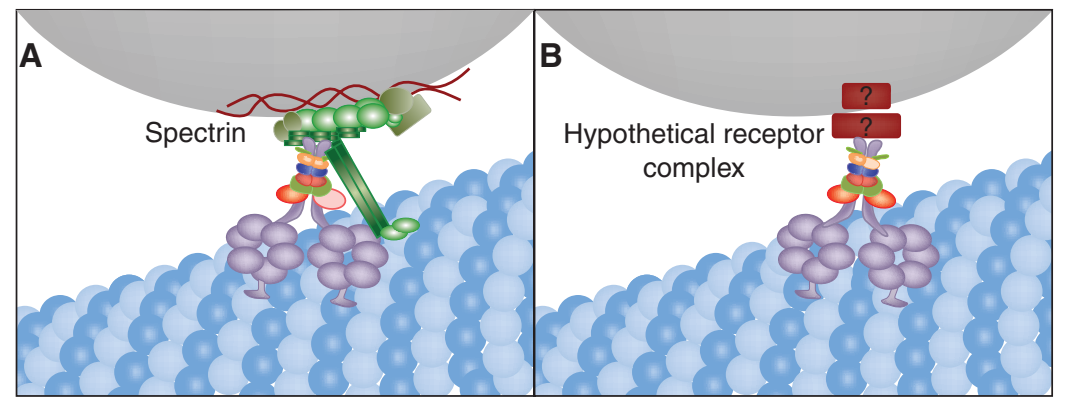

Figure 4. Membrane recruitment of dynein. Golgi membranes are moved inward by dynein moving on microtubules and one possibility is that dynactin links dynein to Golgi membranes by binding spectrin $(A)$. In light of dynactin-independent dynein membrane association and the nonspecific localization of spectrin, another possibility is a yet-to-be-identified receptor complex for dynein that is Golgi-specific $(B)$. 
has problems because the coat is only transiently present on the membrane and although disruption of dynactin binding to sec 23 lowers kinetics of ER to Golgi transport, membrane transport velocities on microtubules are unaffected (Watson et al. 2005; Fromme et al. 2008).

The final category, a compartment specific receptor (Fig. 4B), is appealing but the current candidates each have limitations in explaining how dynein is membrane recruited for ER-toGolgi transport and Golgi positioning. There are a few convincing cases of membrane proteins that bind dynein directly but these are unlikely to be generally involved in either ER-to-Golgi traffic or Golgi positioning. One is rhodopsin, for which the interaction serves to confer dynein-based motility of rhodopsincontaining vesicles, but rhodopsin is only expressed in photoreceptor cells (Tai et al. 1999). Another is Drosophila bicaudal-D and its mammalian homolog BICD2, which localizes to Golgi membranes, microtubule plus tips, and centrosomes (Hoogenraad et al. 2001; Fumoto et al. 2006). Via its amino terminus, BICD-2 binds dynein-dynactin and via its carboxyl terminus, it binds the GTPase rab6 thereby recruiting dynein to rab6 positive membranes (Matanis et al. 2002). Induced targeting of BICD-2 to mitochondria or peroxisomes causes pericentrosomal clustering of the membranes and enhances recruitment of dynein on these membranes (Hoogenraad et al. 2003). Nevertheless, BICD-2 localizes to the TGN, and is involved in COPI independent Golgi to ER transport (Matanis et al. 2002). Further, BICD-2 knockdown does not alter Golgi positioning (Fumoto et al. 2006), hence its involvement in ER-to-Golgi transport and Golgi positioning is unlikely. Golgin-160 and GMAP210 are much better candidates in terms of localization and phenotype. Each is a cisGolgi protein required for minus-end movement of Golgi membrane (Rios et al. 2004; Yadav et al. 2009) and GMAP210 targeted to mitochondria induces their clustering. Nevertheless, whether either protein participates in motor recruitment is unknown. Lava lamp is a peripheral Golgi-associated golgin required for cellularization in the Drosophila embryo (Sisson et al. 2000; Papoulas et al. 2005). Lava lamp provides a link for the motor through associations with spectrin, the dynein complex and CLIP-190 and inhibition of lava lamp blocks dynein-dependent clustering of Golgi membranes. There are no studies of lava lamp outside Drosophila and a mammalian homolog for lava lamp has not yet been identified.

As should be evident, the frequently cited candidates for receptor complexes mediating membrane association of dynein each have shortcomings. For example, dynactin knockdown leaves dynein on the Golgi, BICD-2 is not required for Golgi positioning and lava lamp and others appear to have restricted expression. Further, as noted previously (Linstedt 2004), it is confounding that inhibition or depletion of a multitude of components perturbs Golgi positioning (Table 1). Presumably, this reflects both the dynamic nature of the Golgi apparatus and the dependence of its integrity on many pathways. Thus, the following straightforward criteria for a bona fide receptor complex can be proposed.

a. Knockdown or inhibition must block both dynein localization and Golgi motility.

b. Localization must coincide with dynein on Golgi membranes.

c. Two domains should be evident, one that directly binds a dynein component and one that mediates Golgi localization.

d. Reconstitution in artificial membranes should confer dynein recruitment and motility.

e. Because dynein dissociates from Golgi membranes during mitosis (see below), interaction of dynein with the receptor, or interaction of the receptor with the membrane should be regulated.

\section{Direct Binding to Microtubules and Centrosomes}

Dynein moves Golgi membranes inward but once there, active anchoring or tethering to the centrosome may further maintain pericentrosomal positioning (Fig. 5A). GMAP210 is a 
Golgi Positioning

Table 1. Select proteins showing Golgi phenotypes following knockdown.

\begin{tabular}{|c|c|c|c|c|c|}
\hline Proteins & Localization & $\begin{array}{c}\text { Golgi knockdown } \\
\text { phenotype }\end{array}$ & $\begin{array}{l}\text { Cytoskeletal } \\
\text { interactions }\end{array}$ & $\begin{array}{l}\text { Suggested } \\
\text { functions }\end{array}$ & $\begin{array}{c}\text { References for } \\
\text { Phenotype }\end{array}$ \\
\hline Lava lamp & Drosophila Golgi & $\begin{array}{l}\text { Immotile (no } \\
\text { apical } \\
\text { movement) }\end{array}$ & $\begin{array}{l}\text { Dynein, dynactin, } \\
\text { Clip190, } \\
\alpha \text {-spectrin }\end{array}$ & Motor adaptor & $\begin{array}{l}\text { Papalous et al. } \\
2004\end{array}$ \\
\hline Golgin-160 & cis-Golgi & $\begin{array}{l}\text { Immotile } \\
\text { dispersed stacks }\end{array}$ & Unknown & $\begin{array}{l}\text { Cargo receptor, } \\
\text { motor adaptor? }\end{array}$ & Yadav et al. 2009 \\
\hline GMAP210 & cis-Golgi & $\begin{array}{l}\text { Immotile } \\
\text { dispersed stacks }\end{array}$ & $\begin{array}{l}\text { Microtubules, } \\
\text { Rab2 }\end{array}$ & Tether & Rios et al. 2004 \\
\hline Golgin-245 & trans-Golgi & $\begin{array}{l}\text { Immotile } \\
\text { dispersed stacks }\end{array}$ & $\begin{array}{l}\text { Unknown } \\
\text { (dynein not } \\
\text { detected) }\end{array}$ & $\begin{array}{l}\text { Tether, endosome- } \\
\text { TGN traffic }\end{array}$ & $\begin{array}{l}\text { Yoshino et al. } \\
2005\end{array}$ \\
\hline Dynein & Endomembranes & $\begin{array}{l}\text { Immotile } \\
\text { dispersed stacks }\end{array}$ & $\begin{array}{l}\text { Dynactin, } \\
\text { microtubules }\end{array}$ & Motor & $\begin{array}{l}\text { Harada et al. } \\
1998 \text { Palmer } \\
\text { et al. } 2009\end{array}$ \\
\hline Dynactin & $\begin{array}{l}\text { Centrosome, } \\
\text { +tips }\end{array}$ & $\begin{array}{l}\text { Immotile } \\
\text { dispersed stacks }\end{array}$ & $\begin{array}{l}\text { Dynein, } \\
\text { microtubules }\end{array}$ & $\begin{array}{l}\text { Motor adaptor/ } \\
\text { activator }\end{array}$ & $\begin{array}{l}\text { King and } \\
\quad \text { Schroer } 2000\end{array}$ \\
\hline Huntingtin & $\begin{array}{l}\text { trans-Golgi, } \\
\text { endosomes }\end{array}$ & $\begin{array}{l}\text { Dispersed stacks } \\
\quad \text { (partial) }\end{array}$ & $\begin{array}{l}\text { Dynein, } \\
\text { microtubules }\end{array}$ & $\begin{array}{l}\text { Motor adaptor } \\
\text { (endosome) }\end{array}$ & $\begin{array}{l}\text { Caviston et al. } \\
2007\end{array}$ \\
\hline $\mathrm{BICD} 1 / 2$ & $\begin{array}{l}\text { trans-Golgi } \\
\text { network }\end{array}$ & $\begin{array}{l}\text { Dispersed stacks } \\
\quad \text { (mild) }\end{array}$ & Dynein, Rab6 & $\begin{array}{l}\text { Motor adaptor, } \\
\text { Golgi-ER traffic }\end{array}$ & $\begin{array}{l}\text { Fumoto et al. } \\
2006\end{array}$ \\
\hline Golgin-97 & trans-Golgi & Dispersed stacks & Unknown & $\begin{array}{l}\text { Tether, endosome- } \\
\text { TGN traffic }\end{array}$ & Lu et al. 2004 \\
\hline Golgin-84 & trans-Golgi & Dispersed stacks & Unknown & $\begin{array}{l}\text { Tether, intra-Golgi } \\
\text { retrograde traffic }\end{array}$ & Diao et al. 2003 \\
\hline GCC185 & trans-Golgi & Dispersed stacks & CLASP $1 / 2$ & $\begin{array}{l}\text { Microtubule } \\
\text { anchor, tether }\end{array}$ & $\begin{array}{l}\text { Derby et al. } \\
2007\end{array}$ \\
\hline MyosinVI & Golgi & Dispersed stacks & Optineurin & Motor & $\begin{array}{l}\text { Warner et al. } \\
2003\end{array}$ \\
\hline Optineurin & Golgi & Dispersed stacks & MysoinVI & Motor adaptor & $\begin{array}{l}\text { Sahlender et al. } \\
\quad 2005\end{array}$ \\
\hline ZW-10 & ER, Golgi & Dispersed stacks & Dynein, dynactin & $\begin{array}{l}\text { Tether, motor } \\
\text { adaptor at } \\
\text { kinetochore }\end{array}$ & $\begin{array}{l}\text { Hirose et al. } \\
2004\end{array}$ \\
\hline Rab2 & cis-Golgi, ERGIC & Dispersed stacks & $\begin{array}{l}\text { Dynein, } \\
\text { microtubules }\end{array}$ & $\begin{array}{l}\text { GTPase, } \\
\text { ER-to-Golgi }\end{array}$ & $\begin{array}{l}\text { Tisdale et al. } \\
1999\end{array}$ \\
\hline Rab18 & cis-Golgi & Dispersed stacks & Unknown & $\begin{array}{l}\text { GTPase, } \\
\text { ER-to-Golgi }\end{array}$ & $\begin{array}{l}\text { Dejgaard et al. } \\
2008\end{array}$ \\
\hline Rab43 & cis-Golgi & Dispersed stacks & Unknown & $\begin{array}{l}\text { GTPase, } \\
\text { ER-to-Golgi }\end{array}$ & $\begin{array}{l}\text { Dejgaard et al. } \\
2008\end{array}$ \\
\hline Rab6 & trans-Golgi & Dispersed stacks & Dynein & $\begin{array}{l}\text { GTPase, } \\
\text { Golgi-to-ER }\end{array}$ & $\begin{array}{l}\text { Young et al. } \\
2005\end{array}$ \\
\hline Hook3 & Centrosome & $\begin{array}{l}\text { Dispersed stacks } \\
\quad \text { (on } \\
\text { overexpression) }\end{array}$ & PCM1 & $\begin{array}{l}\text { Centrosome } \\
\text { anchor }\end{array}$ & $\begin{array}{l}\text { Walenta et al. } \\
2001\end{array}$ \\
\hline CLASP1/2 & Golgi, + tips & $\begin{array}{l}\text { Unlinked } \\
\text { clustered stacks }\end{array}$ & $\begin{array}{l}\text { CLIP, EB1, + tip } \\
\text { proteins }\end{array}$ & $\begin{array}{l}\text { Microtubule } \\
\text { anchor (Golgi) } \\
\text { \& regulator }\end{array}$ & $\begin{array}{l}\text { Mimori } \\
\quad \text { Kiyosue et al. } \\
2005\end{array}$ \\
\hline
\end{tabular}


S. Yadav and A.D. Linstedt

Table 1. Continued

\begin{tabular}{|c|c|c|c|c|c|}
\hline Proteins & Localization & $\begin{array}{l}\text { Golgi knockdown } \\
\text { phenotype }\end{array}$ & $\begin{array}{l}\text { Cytoskeletal } \\
\text { interactions }\end{array}$ & $\begin{array}{l}\text { Suggested } \\
\text { functions }\end{array}$ & $\begin{array}{l}\text { References for } \\
\text { Phenotype }\end{array}$ \\
\hline GRASP55 & Medial Golgi & $\begin{array}{l}\text { Unlinked } \\
\text { clustered stacks }\end{array}$ & Unknown & $\begin{array}{l}\text { Stacking, linking, } \\
\text { cargo receptor }\end{array}$ & $\begin{array}{l}\text { Feinstein and } \\
\text { Linstedt } 2007\end{array}$ \\
\hline GRASP65 & cis-Golgi & $\begin{array}{l}\text { Unlinked } \\
\text { clustered stacks }\end{array}$ & Unknown & $\begin{array}{l}\text { Stacking, linking, } \\
\text { cargo receptor }\end{array}$ & $\begin{array}{l}\text { Puthenveedu } \\
\text { et al. } 2006\end{array}$ \\
\hline GM130 & cis-Golgi & $\begin{array}{l}\text { Unlinked } \\
\text { clustered stacks }\end{array}$ & Unknown & $\begin{array}{l}\text { Stacking, linking, } \\
\text { cargo receptor, } \\
\text { scaffold }\end{array}$ & $\begin{array}{r}\text { Puthenveedu } \\
\text { et al. } 2006\end{array}$ \\
\hline Golgin-45 & Medial Golgi & $\begin{array}{l}\text { Unlinked } \\
\text { clustered stacks }\end{array}$ & Unknown & $\begin{array}{l}\text { Stacking, linking, } \\
\text { cargo receptor, } \\
\text { scaffold }\end{array}$ & Short et al. 2001 \\
\hline p115 & ERGIC, cis-Golgi & $\begin{array}{l}\text { Dispersed } \\
\text { vesiculated } \\
\text { Golgi }\end{array}$ & Unknown & Tether & $\begin{array}{l}\text { Puthenveedu } \\
\text { and Linstedt } \\
2004\end{array}$ \\
\hline Rab1 & ERGIC & $\begin{array}{l}\text { Dispersed } \\
\text { vesiculated } \\
\text { Golgi }\end{array}$ & Unknown & $\begin{array}{l}\text { GTPase, } \\
\text { ER-to-Golgi }\end{array}$ & $\begin{array}{l}\text { Wilson et al. } \\
1994\end{array}$ \\
\hline Spectrin & Endomembranes & Unknown & Arp1 & $\begin{array}{l}\text { Scaffold, motor } \\
\text { adaptor }\end{array}$ & $\begin{array}{l}\text { Holleran et al. } \\
2001\end{array}$ \\
\hline
\end{tabular}

Proteins are grouped according to phenotype. Listed interactions are only those most closely related to the cytoskeleton and motility. Possible functions are noted but most are beyond the scope of this review and not discussed. Citations are restricted to those initially describing the knockdown phenotypes.

candidate as it not only binds the Golgi but also binds directly to $\gamma$-tubulin at the minus-ends of microtubules (Infante et al. 1999). Its carboxyl terminus, when exogenously expressed, localizes to centrosomes (Cardenas et al. 2009). However, GMAP210 has also been implicated in motility (see above) and in vesicle tethering
(Drin et al. 2007; Drin et al. 2008). Another protein that may link the Golgi to centrosomes is Hook 3 because it binds Golgi membranes via its amino-terminal domain and binds centrosomes and microtubules via its carboxy-terminal domain. Further, Hook3 overexpression fragments the Golgi (Walenta et al. 2001).

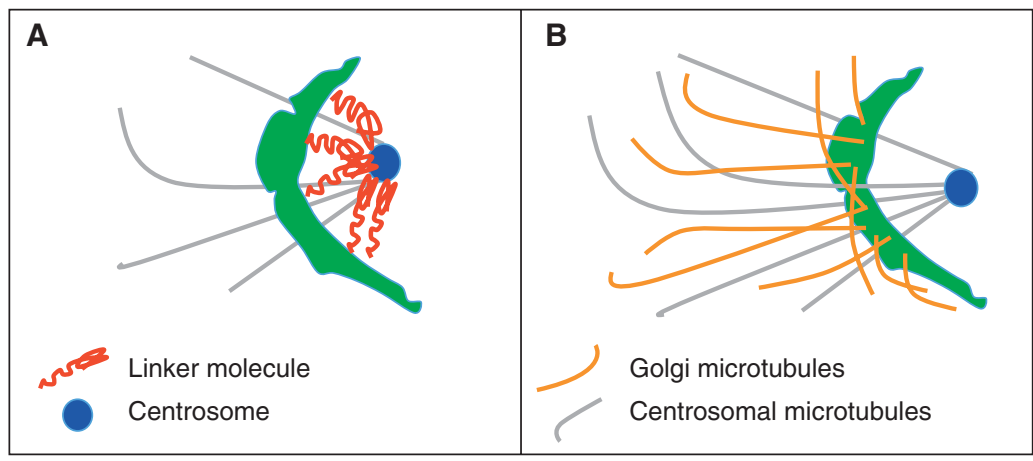

Figure 5. Additional Golgi positioning mechanisms. Golgi membranes may be anchored directly to the centrosome and/or minus-ends of microtubules $(A)$. Golgi microtubules contribute to Golgi structure and maintenance of Golgi positioning once the membranes have moved inward $(B)$. 


\section{Cytoskeleton-Mediated Golgi Stabilization}

Recently, a distinct subset of microtubules that are nucleated at the Golgi apparatus rather than the centrosome (Fig. 5B) was characterized, and these are required for integrity of the Golgi ribbon (Miller et al. 2009). Golgi-nucleated microtubules are readily apparent during microtubule repolymerization after nocodazole washout of cells with ablated centrosomes (Efimov et al. 2007). These microtubules cluster Golgi stacks but centrosomal microtubules are required for pericentrosomal positioning of Golgi membranes indicating that Golgi microtubules play a more direct role in maintenance of Golgi structure than in positioning (Miller et al. 2009). Nevertheless, Golgi positioning is maintained on centrosome ablation indicating that Golgi microtubules stabilize Golgi positioning after dynein-mediated inward movement on centrosomal microtubules (Efimov et al. 2007).

Actin filaments are also present on Golgi membranes and implicated in Golgi integrity. Interestingly, myosin VI a minus-end actin motor binds to the Golgi through a Rab8 mediated interaction with optineurin and knockdown of optineurin fragments the Golgi (Sahlender et al. 2005).

Multiple Motor Regulation and Bidirectional Movement

Increasing evidence indicates that most motile membranes are simultaneously associated with plus- and minus-end directed motors and directionality of membrane movement is not determined by a 'tug-of-war' between the opposing motors but rather by specific regulation of either motor activity (Vale 2003; Welte 2004). Further, inhibition of either dynein or kinesin blocks both plus- and minus-end directed movement, indicating that motors of opposite polarity are somehow interdependent for activity (Brady et al. 1990; Martin et al. 1999; Deacon et al. 2003). The presence of both motors on Golgi membranes is likely advantageous for membrane remodeling involving bidirectional movements, whether the movements are different Golgi domains moving simultaneously in opposite directions or one domain switching from one direction to another. It also allows obstacles to be bypassed by backtracking before further forward movement (Welte 2004). Interestingly, the p150 subunit of dynactin not only binds dynein but also binds the KAP subunit of kinesin-II and these interactions are competitive (Deacon et al. 2003). Dynactin binding to the two motors is probably not for their recruitment because, as mentioned above, the motors remain on Golgi membranes after dynactin depletion (Haghnia et al. 2007). Rather, dynactin could alternate binding between the motors regulating their activity to confer directionality (Gross 2003).

\section{REGULATION OF GOLGI POSITIONING}

The characteristic positioning of the Golgi ribbon in interphase mammalian cells is dynamic and dramatically changes during several cellular processes (Fig. 6). This section covers the current understanding of how Golgi membrane positioning is subject to regulation. Structural changes vary from complete fragmentation and loss of motility of the Golgi apparatus during mitosis and apoptosis, to comparatively subtle remodeling and repositioning of the Golgi membranes during cell migration and differentiation.

\section{Golgi Fragmentation and Loss of Positioning}

\section{Mitosis}

The Golgi apparatus in mammalian cells undergoes stepwise fragmentation during mitosis. During this period, microtubules are rearranged to form the mitotic spindle and the fragmented Golgi membranes become dispersed throughout the dividing cell. Although the mechanism of Golgi fragmentation during mitosis has been extensively studied, less is known about mitotic regulation of Golgi motility. Because mitotic Golgi membranes disperse rather than accumulate at spindle poles, it is clear that inward Golgi membrane motility is inhibited during mitosis. Indeed, in vitro experiments using Xenopus egg extracts from mitotic and interphase cells reveal that the minus-end movement of membranes in severely inhibited at 
S. Yadav and A.D. Linstedt

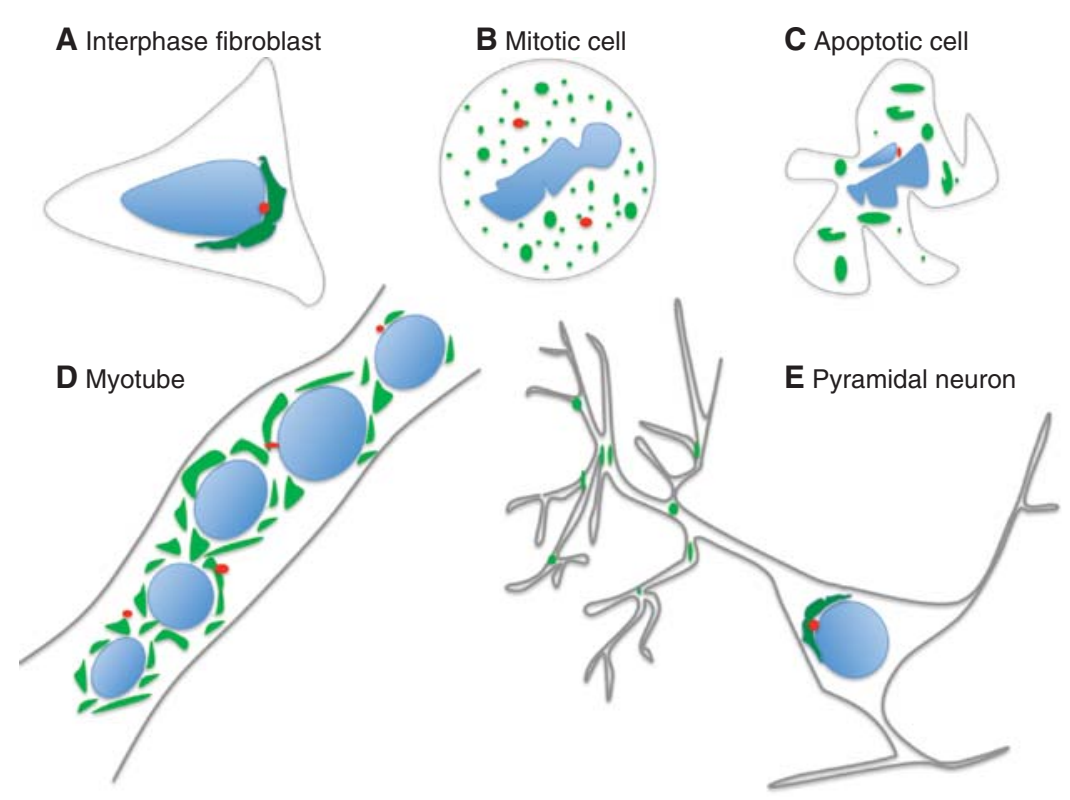

Figure 6. Dynamic changes in Golgi positioning. Golgi membranes are positioned adjacent the centrosome in many mammalian cell types during interphase $(A)$ and fragment and disperse during mitosis $(B)$ and apoptosis $(C)$. The pericentrosomal Golgi ribbon in myoblasts is converted to dispersed Golgi ministacks in myotubes (D). Pyramidal neurons have both a somatic Golgi and dispersed Golgi-outposts, which localize to dendritic branchpoints $(E)$.

M-phase (Allan and Vale 1991). This is the consequence of motor dissociation from the membranes rather than inhibition of the motor itself (Niclas et al. 1996). A possible mechanism is the phosphorylation of DLIC by the key mitotic kinase, cyclin-dependent kinase 1 (CDK1). ACDK1 site in DLIC has been mapped (Dell et al. 2000) and, in another study, CDK1 caused dissociation of DLIC from isolated Golgi membranes (Addinall et al. 2001). Whether mutation of the phosphorylation site actually blocks dynein disassociation in mitotic cells still needs to be tested. DIC is also mitotically phosphorylated (Vaughan et al. 2001) and, under this condition, it switches from binding dynactin to binding the kinetochore-localized RZZ complex (Whyte et al. 2008). In anaphase, DIC is dephosphorylated and rebinds dynactin but this initiates chromosome separation rather than inward Golgi membrane movement. Golgi membranes begin to accumulate at microtubule minus-ends in late anaphase and telophase indicating that the motor rebinds Golgi membranes at these stages but the control mechanism activating recruitment is not known. The significance of Golgi dispersal at M-phase is likely multifold. In late G2 phase, the Golgi ribbon unlinks and this may remove steric hindrance to allow centrosome separation. Because inhibition of Golgi unlinking delays onset of mitosis, it is also possible that the degree of Golgi fragmentation provides feedback control impinging on cell cycle regulators (Colanzi et al. 2007; Feinstein and Linstedt 2007). Finally, and perhaps most importantly, uniform dispersal of Golgi-derived vesicles at the beginning of anaphase provides a simple way to ensure equal partitioning of Golgi membranes into daughter cells.

\section{Apoptosis}

The Golgi ribbon in mammalian cells undergoes fragmentation during apoptosis but, unlike mitotic disassembly, apoptotic disassembly is irreversible. Apoptosis can be caused by 
internal stress or extrinsic factors and involves a proteolytic cascade of caspases leading to organelle and cytoskeleton disassembly as well as membrane blebbing and ultimately cell death. Caspases cleave several proteins important for Golgi structure including golgin-160 (Mancini et al. 2000), GRASP65 (Lane et al. 2002), p115 (Chiu et al. 2002), GM130 (Nozawa et al. 2002), and giantin (Lowe et al. 2004). Interestingly, Golgi fragmentation precedes actin and microtubule disassembly (Mukherjee et al. 2007) implying that dispersal of Golgi membranes is because of loss of dynein recruitment or activity. In this regard, it is noteworthy that golgin-160, which is required for Golgi motility, is cleaved (Mancini et al. 2000) and also that both DIC and the dynactin component p150 undergo caspase-dependent cleavage (Lane et al. 2001). Intriguingly, for several of the Golgi-localized proteins, including golgin-160, preventing their cleavage slows or blocks apoptosis. Although this hampers a definitive test of the role of golgin-160 cleavage in Golgi dispersal, experiments show that golgin-160 cleavage, as well as p115 cleavage, actually contributes to specific aspects of apoptotic signaling (Maag et al. 2005; Mukherjee and Shields 2009). This likely has more to do with roles of the cleaved products, for example in possibly activating transcriptional changes, than in causing Golgi dispersal (Maag et al. 2005).

\section{Golgi Membrane Remodeling and Reorientation}

\section{Cell Differentiation}

Golgi positioning is dramatically altered during differentiation of myoblasts into myotubes (Ralston 1993). In about $1-2 \mathrm{~h}$ the pericentrosomal Golgi ribbon becomes fragmented into isolated Golgi stacks encircling the nuclei of the fused cells of a myotube. The mechanism of the change is unclear, but centrosomal proteins and ER exit sites are also reorganized, each also encircling the nuclei. Microtubules are also reorganized and at least part of the Golgi change may be because of uncoupling Golgi positioning from its inward motility ( $\mathrm{Lu}$ et al.
2001). Interestingly, these changes are early steps prior to cell fusion and could be an obligate part of the differentiation pathway (Lu et al. 2001).

Differentiation of uroepithelial cells to form uraplakin-positive uroepithelial cells is also marked by fragmentation of the pericentrosomal Golgi ribbon present in the undifferentiated cells. Golgi dispersal appears to promote uniform delivery of uroplakins over the apical plasma membrane, which is critical to the formation and maintenance of the blood-urine barrier (Kreft et al. 2010).

Golgi membranes during meiotic maturation and fertilization in mammalian oocytes undergo interesting dynamics. In nonrodent mammalian oocyte development, including human, the maturing gamete lacks a centrosome until the sperm introduces it during fertilization (Schatten 1994). As might be expected for cells lacking a centrosome the Golgi is present as dispersed fragments in the cytoplasm (Moreno et al. 2002). As the oocyte matures and is arrested at metaphase II of meiosis the Golgi breaks down further yielding punctae coincident with ER exit sites, presumably akin to mitotic breakdown. Following fertilization, the Golgi membranes coalesce near the nucleus of the zygote but do not form intact ribbon networks until the two-cell stage is reached (Payne and Schatten 2003). Although it remains to be tested, these rearrangements could largely reflect normal zygotic control of Golgi positioning through microtubule organization and cellcycle dependent motor recruitment. In support of this, Golgi function may be unnecessary during oocyte maturation because a brefeldin A-induced block of secretion has no apparent effect on maturation of the oocyte.

\section{Cell Polarization and Migration}

In response to certain external cues, cells reorganize their cytoskeleton and thereby their secretory system to achieve polarization that promotes directional migration toward the cue (Kupfer et al. 1982). Primary polarization cues initiated at the cell's leading edge activate the GTPase Cdc42, which establishes the Par6-Par3-PKC polarity complex. This complex 
recruits and anchors dynein, which pulls on astral microtubules to reorient the centrosome toward the leading edge (Palazzo et al. 2001). This, in turn, aligns the Golgi toward the leading edge. Interestingly, unlinking of the Golgi ribbon appears to be required for Golgi reorientation. The Golgi linking protein GRASP65 is phosphorylated during reorientation and expression of a nonphosphorylatable form of GRASP65 blocks centrosome reorientation (Bisel et al. 2008). Significantly, this block is neutralized if the Golgi is fragmented by other means. The GRASP65 binding partner GM130 is also involved but in a distinct manner. GM130 recruits and activates the kinase YSK1, which phosphorylates downstream targets involved in cell polarity. Expression of dominant negative YSK1 blocks reorientation of both the centrosome and the Golgi apparatus (Preisinger et al. 2004) indicating the involvement of GM130 and YSK1 in polarization signaling.

\section{PHYSIOLOGICAL IMPORTANCE OF GOLGI POSITIONING}

Why do mammalian cells have a pericentrosomal Golgi apparatus when dispersed stacks are fully functional in core processing and sorting reactions? Cell types with dispersed Golgi, such as in plants and yeast, use other mechanisms to direct secretion to a plasma membrane subdomain (Preuss et al. 1992; Stanley et al. 1997; Nebenfuhr et al. 2000; Herpers and Rabouille 2004). Recent work indicates that Golgi positioning in mammalian cells has largely to do with maintenance of the polarized state such that secretion is more readily directed to a specialized cellular domain. Distinct cell types use this polarity to different ends and examples of this are provided below.

\section{Polarized Secretion, Cell Polarity, and Migration}

Migrating fibroblasts respond to wounding, electric fields or to chemotactic gradients, such that the Golgi apparatus (Kupfer et al. 1982) and the centrosome are repositioned to face the direction of the stimuli, which then defines the cell's leading edge (Fig. 7A). Secretion is required for maintaining cell polarity (Bershadsky and Futerman 1994; Prigozhina and Waterman-Storer 2004) and secretion becomes directed to the leading edge during the polarity response (Schmoranzer et al. 2003). As a consequence the Golgi provides membrane and secreted products directly to the site of stimulus. In principle, targeted delivery could occur without a reoriented Golgi. For example, it could be achieved solely by polarizing the cytoskeleton or by restricting vesicle-docking sites to the leading edge. However, this is not how it works because specific disruption of Golgi orientation blocks directed secretion (Yadav et al. 2009). In these experiments, Golgi positioning was disrupted by knockdown of either golgin-160 or GMAP210 yielding dispersed ministacks but leaving the cytoskeleton intact. The cells continued to secrete but failed to target the leading edge and as a consequence the polarized state was not achieved and the cells failed to migrate in response to wounding. An interesting possibility is that polarity is initiated at the leading edge but its maintenance depends on directed delivery from the Golgi of polarity-sustaining components (Fig. 7B).

\section{Furrow Formation During Cellularization}

Cellularization of the Drosophila melanogaster syncytial embryo requires secretion from a reoriented Golgi to build the membrane furrows that encapsulate the nuclei (Sisson et al. 2000). In the syncytial embryo, Golgi membranes are dispersed stacks and their dyneindependent movement and coalescence at the apical side of the nucleus marks cellularization. Blocking the Golgi membrane movement blocks cellularization presumably because Golgi positioning focuses secretion on the growing furrows (Papoulas et al. 2005).

\section{Immunological Synapse}

Natural killer cells and cytotoxic $\mathrm{T}$ cells form an immunological synapse with target cells in which they release lytic factors that kill the target cell. During this process Golgi membranes and the centrosome are repositioned to face 
Golgi Positioning

A

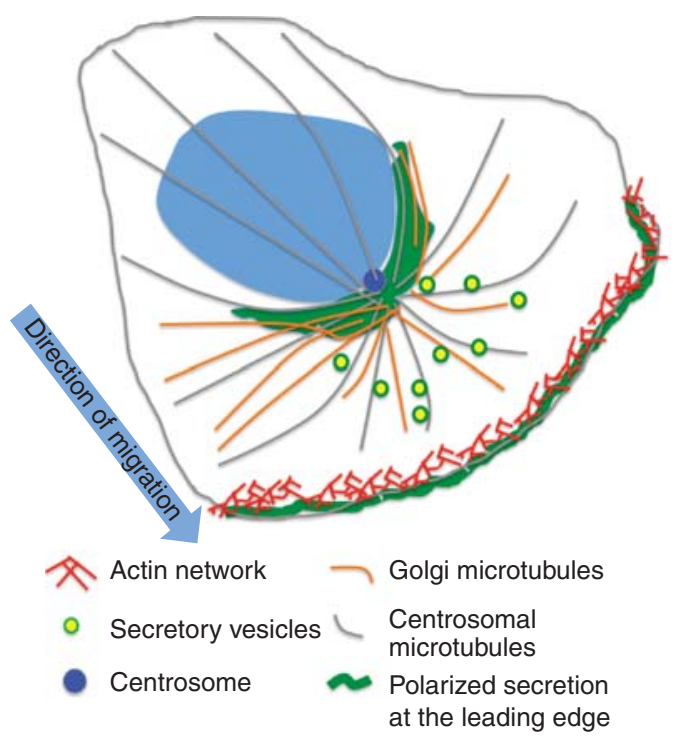

B

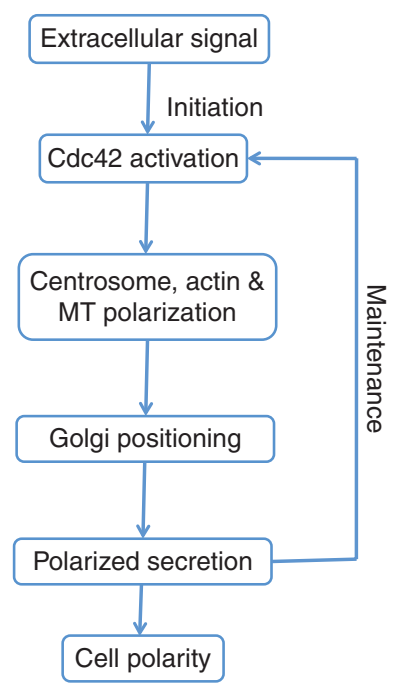

Figure 7. Golgi positioning directs secretion to cell leading edge. Extracellular signals, such as wounding, trigger actin assembly and reorientation of the centrosome, the Golgi apparatus, and the microtubule array $(A)$. As a consequence, secretion is directed to the leading edge. Once initiated, maintenance of polarity requires directed secretion toward the leading edge by the pericentrosomally positioned Golgi apparatus $(B)$.

the area of cell-cell contact (Kupfer et al. 1983; Stinchcombe et al. 2006). This reorientation likely provides a mechanism for vectorial secretion of effector molecules at the immunological synapse. Interestingly, there is a specialized case in which not only the $\mathrm{T}$ cell Golgi reorients but also the Golgi in the target cell. During cellular injury or viral invasion, $\mathrm{T}$ cells form contacts with brain astrocytes, which normally have multiple plasma membrane extensions. Following contact, the astrocytes reorganize, extending a single protrusion terminated by the immunological synapse. The centrosome and Golgi are positioned in the protrusion and targeted secretion to the synapse by the astrocyte may determine whether or not the astrocyte is killed or withstands the $\mathrm{T}$ cell attack (Barcia et al. 2008).

\section{Axon Specification and Dendritic Arborization}

Axon specification is a fundamental process during neuronal development that depends on a polarized cytoskeleton and secretory machinery (Bradke and Dotti 1997). Axon formation in hippocampal cells occurs opposite the plane of mitotic division at a site faced by the Golgi apparatus and centrosome (de Anda et al. 2005). Interestingly, in the presence of two centrosomes and Golgi, two separate axons form. In fact, in cerebellar granule neurons, bipolar morphology is achieved in a two-step process. The initial extension of a single neuronal process at a site aligned with the Golgi is followed by repositioning of the Golgi to the other side of the nucleus and the formation there of a second axon (Zmuda and Rivas 1998).

Golgi orientation has also been linked to dendrites. Indeed, one study noted that the cell body-localized, or somatic, Golgi was always oriented toward dendrites and knockdown of GRASP65 to fragment the Golgi altered dendritic rather than axonal outgrowth (Horton et al. 2005). Further, Golgi elements are not exclusively somatic but also present in dendrites as multiple Golgi "outposts." Golgi outposts localize selectively to dendritic branchpoints and are typically present in only one long 
dendrite (Horton and Ehlers 2003). Golgi outposts depend on dynein-based movement for this positioning and in Drosophila neurons, knockdown of lava lamp, the golgin that mediates motor attachment to Golgi membranes in these cells, causes loss of dendritic branch points. Further, the lava lamp knockdown causes Golgi outposts to appear in axons and these axons start branching. Therefore, positioning of Golgi outposts is critical in conferring dendritic arborization (Ye et al. 2007).

\section{CONCLUDING REMARKS}

Golgi pericentrosomal positioning is a striking feature of mammalian cells. It is largely the result of secretory and Golgi membrane movement toward the minus-ends of microtubules by the dynein motor complex. An exciting area of research continues to be the functional characterization of both the core and the regulatory subunits of dynein and how they confer functional diversity to the motor. Further, it is critical that the identity of the membrane receptor complex for dynein on the Golgi becomes more clearly elucidated if we are to understand how Golgi positioning is regulated. Membrane association of the motor is regulated during mitosis. It is likely also regulated during cycles of membrane capture and release for inward secretory and Golgi movements. Significantly, Golgi-nucleated microtubules provide a new perspective on how Golgi positioning may be maintained after inward movement. It will be interesting to see how and when Golgi microtubules are regulated and to determine their prevalence in different organisms and cell types. It is arguable that most changes in Golgi positioning are either the result of uncoupling Golgi membranes from the motor or a consequence of a rearranged centrosome-meditated microtubule array. The latter appears to be used to great effect in cells that orient their Golgi to perform directed secretion toward sites of rapid or specialized growth. Nevertheless, Golgi positioning is one of many changes occurring in these cells. Tests that specifically change Golgi positioning are needed to confirm its importance in these diverse processes. Although it is difficult to imagine how an intact Golgi ribbon network could be experimentally moved to new cellular location, it is clear that increased understanding of the machinery controlling motor membrane attachment will allow development of reagents that specifically block Golgi fragmentation, coalescence or reorientation. Such reagents will not only be instrumental as further tests of the physiological importance of Golgi positioning, but also will undoubtedly reveal new insights into special functions conferred by a positioned Golgi.

\section{REFERENCES}

Addinall SG, Mayr PS, Doyle S, Sheehan JK, Woodman PG, Allan VJ. 2001. Phosphorylation by cdc2-CyclinB1 kinase releases cytoplasmic dynein from membranes. J Biol Chem 276: 15939-15944.

Allan VJ, Vale RD. 1991. Cell cycle control of microtubulebased membrane transport and tubule formation in vitro. J Cell Biol 113: 347-359.

Arasaki K, Taniguchi M, Tani K, Tagaya M. 2006. RINT-1 regulates the localization and entry of ZW10 to the syntaxin 18 complex. Mol Biol Cell 17: 2780-2788.

Askham JM, Vaughan KT, Goodson HV, Morrison EE. 2002. Evidence that an interaction between EB1 and p150(Glued) is required for the formation and maintenance of a radial microtubule array anchored at the centrosome. Mol Biol Cell 13: 3627-3645.

Barcia C, Sanderson NS, Barrett RJ, Wawrowsky K, Kroeger KM, Puntel M, Liu C, Castro MG, Lowenstein PR. 2008. $\mathrm{T}$ cells' immunological synapses induce polarization of brain astrocytes in vivo and in vitro: A novel astrocyte response mechanism to cellular injury. PLoS One 3: e2977.

Bershadsky AD, Futerman AH. 1994. Disruption of the Golgi apparatus by brefeldin A blocks cell polarization and inhibits directed cell migration. Proc Natl Acad Sci 91: 5686-5689.

Bisel B, Wang Y, Wei JH, Xiang Y, Tang D, Miron-Mendoza M, Yoshimura S, Nakamura N, Seemann J. 2008. ERK regulates Golgi and centrosome orientation towards the leading edge through GRASP65. J Cell Biol 182: 837-843.

Bradke F, Dotti CG. 1997. Neuronal polarity: vectorial cytoplasmic flow precedes axon formation. Neuron 19: 1175-1186.

Brady ST, Pfister KK, Bloom GS. 1990. A monoclonal antibody against kinesin inhibits both anterograde and retrograde fast axonal transport in squid axoplasm. Proc Natl Acad Sci 87: 1061-1065.

Cardenas J, Rivero S, Goud B, Bornens M, Rios RM. 2009. Golgi localisation of GMAP210 requires two distinct cismembrane binding mechanisms. BMC Biol 7: 56

Chiu R, Novikov L, Mukherjee S, Shields D. 2002. A caspase cleavage fragment of p115 induces fragmentation of the Golgi apparatus and apoptosis. J Cell Biol 159: 637-648. 
Colanzi A, Hidalgo Carcedo C, Persico A, Cericola C, Turacchio G, Bonazzi M, Luini A, Corda D. 2007. The Golgi mitotic checkpoint is controlled by BARS-dependent fission of the Golgi ribbon into separate stacks in G2. Embo J 26: $2465-2476$.

de Anda FC, Pollarolo G, Da Silva JS, Camoletto PG, Feiguin F, Dotti CG. 2005. Centrosome localization determines neuronal polarity. Nature 436: 704-708.

De Matteis MA, Morrow JS. 2000. Spectrin tethers and mesh in the biosynthetic pathway. J Cell Sci 113: 2331-2343.

Deacon SW, Serpinskaya AS, Vaughan PS, Lopez Fanarraga M, Vernos I, Vaughan KT, Gelfand VI. 2003. Dynactin is required for bidirectional organelle transport. J Cell Biol 160: 297-301.

Dell KR, Turck CW, Vale RD. 2000. Mitotic phosphorylation of the dynein light intermediate chain is mediated by cdc2 kinase. Traffic 1: 38-44.

Drin G, Casella JF, Gautier R, Boehmer T, Schwartz TU, Antonny B. 2007. A general amphipathic $\alpha$-helical motif for sensing membrane curvature. Nat Struct Mol Biol 14: $138-146$.

Drin G, Morello V, Casella JF, Gounon P, Antonny B. 2008 Asymmetric tethering of flat and curved lipid membranes by a golgin. Science 320: 670-673.

Efimov A, Kharitonov A, Efimova N, Loncarek J, Miller PM, Andreyeva N, Gleeson P, Galjart N, Maia AR, McLeod IX, et al. 2007. Asymmetric CLASP-dependent nucleation of noncentrosomal microtubules at the trans-Golgi network. Dev Cell 12: 917-930.

Feinstein TN, Linstedt AD. 2007. Mitogen-activated protein kinase kinase 1-dependent Golgi unlinking occurs in G2 phase and promotes the G2/M cell cycle transition. $\mathrm{Mol}$ Biol Cell 18: 594-604.

Ferro KL, Collins CA. 1995. Microtubule-independent phospholipid stimulation of cytoplasmic dynein ATPase activity. J Biol Chem 270: 4492-4496.

Fromme JC, Orci L, Schekman R. 2008. Coordination of COPII vesicle trafficking by Sec23. Trends Cell Biol 18: 330-336.

Fumoto K, Hoogenraad CC, Kikuchi A. 2006. GSK-3ßregulated interaction of BICD with dynein is involved in microtubule anchorage at centrosome. Embo J 25: 5670-5682.

Gross SP. 2003. Dynactin: coordinating motors with opposite inclinations. Curr Biol 13: R320-322.

Haghnia M, Cavalli V, Shah SB, Schimmelpfeng K, Brusch R, Yang G, Herrera C, Pilling A, Goldstein LS. 2007. Dynactin is required for coordinated bidirectional motility, but not for dynein membrane attachment. Mol Biol Cell 18: 2081-2089.

Harada A, Takei Y, Kanai Y, Tanaka Y, Nonaka S, Hirokawa N. 1998. Golgi vesiculation and lysosome dispersion in cells lacking cytoplasmic dynein. J Cell Biol 141: 51-59.

Herpers B, Rabouille C. 2004. mRNA localization and ER-based protein sorting mechanisms dictate the use of transitional endoplasmic reticulum-golgi units involved in gurken transport in Drosophila oocytes. Mol Biol Cell 15: 5306-5317.

Hirose H, Arasaki K, Dohmae N, Takio K, Hatsuzawa K, Nagahama M, Tani K, Yamamoto A, Tohyama M, Tagaya M. 2004. Implication of ZW10 in membrane trafficking between the endoplasmic reticulum and Golgi. Embo J 23: $1267-1278$.

Holleran EA, Ligon LA, Tokito M, Stankewich MC, Morrow JS, Holzbaur EL. 2001. $\beta$ III spectrin binds to the Arp1 subunit of dynactin. J Biol Chem 276: 36598-36605.

Hoogenraad CC, Akhmanova A, Howell SA, Dortland BR, De Zeeuw CI, Willemsen R, Visser P, Grosveld F, Galjart N. 2001. Mammalian Golgi-associated Bicaudal-D2 functions in the dynein-dynactin pathway by interacting with these complexes. Embo J 20: 4041-4054.

Hoogenraad CC, Wulf P, Schiefermeier N, Stepanova T, Galjart N, Small JV, Grosveld F, de Zeeuw CI, Akhmanova A. 2003. Bicaudal D induces selective dynein-mediated microtubule minus end-directed transport. Embo J 22: 6004-6015.

Horton AC, Ehlers MD. 2003. Dual modes of endoplasmic reticulum-to-Golgi transport in dendrites revealed by live-cell imaging. J Neurosci 23: 6188-6199.

Horton AC, Racz B, Monson EE, Lin AL, Weinberg RJ, Ehlers MD. 2005. Polarized secretory trafficking directs cargo for asymmetric dendrite growth and morphogenesis. Neuron 48: 757-771.

Infante C, Ramos-Morales F, Fedriani C, Bornens $\mathrm{M}$, Rios RM. 1999. GMAP-210, A cis-Golgi network-associated protein, is a minus end microtubule-binding protein. J Cell Biol 145: 83-98.

Inoue M, Arasaki K, Ueda A, Aoki T, Tagaya M. 2008. $\mathrm{N}$-terminal region of ZW10 serves not only as a determinant for localization but also as a link with dynein function. Genes Cells 13: 905-914.

Kardon JR, Vale RD. 2009. Regulators of the cytoplasmic dynein motor. Nat Rev Mol Cell Biol 10: 854-865.

King SJ, Schroer TA. 2000. Dynactin increases the processivity of the cytoplasmic dynein motor. Nat Cell Biol 2: 20-24.

King SJ, Bonilla M, Rodgers ME, Schroer TA. 2002. Subunit organization in cytoplasmic dynein subcomplexes. Protein Sci 11: 1239-1250.

Kreft ME, Di Giandomenico D, Beznoussenko GV, Resnik N, Mironov AA, Jezernik K. 2010. Golgi apparatus fragmentation as a mechanism responsible for uniform delivery of uroplakins to the apical plasma membrane of uroepithelial cells. Biol Cell 102: 593-607.

Kupfer A, Dennert G, Singer SJ. 1983. Polarization of the Golgi apparatus and the microtubule-organizing center within cloned natural killer cells bound to their targets. Proc Natl Acad Sci 80: 7224-7228.

Kupfer A, Louvard D, Singer SJ. 1982. Polarization of the Golgi apparatus and the microtubule-organizing center in cultured fibroblasts at the edge of an experimental wound. Proc Natl Acad Sci 79: 2603-2607.

Lacey ML, Haimo LT. 1994. Cytoplasmic dynein binds to phospholipid vesicles. Cell Motil Cytoskeleton 28: 205-212.

Lane JD, Lucocq J, Pryde J, Barr FA, Woodman PG, Allan VJ, Lowe M. 2002. Caspase-mediated cleavage of the stacking protein GRASP65 is required for Golgi fragmentation during apoptosis. J Cell Biol 156: 495-509.

Lane JD, Vergnolle MA, Woodman PG, Allan VJ. 2001. Apoptotic cleavage of cytoplasmic dynein intermediate 
chain and p150(Glued) stops dynein-dependent membrane motility. J Cell Biol 153: 1415-1426.

Linstedt AD. 2004. Positioning the Golgi apparatus. Cell 118: $271-272$

Lowe M, Lane JD, Woodman PG, Allan VJ. 2004. Caspasemediated cleavage of syntaxin 5 and giantin accompanies inhibition of secretory traffic during apoptosis. J Cell Sci 117: 1139-1150.

Lu Z, Joseph D, Bugnard E, Zaal KJ, Ralston E. 2001. Golgi complex reorganization during muscle differentiation: visualization in living cells and mechanism. Mol Biol Cell 12: 795-808.

Maag RS, Mancini M, Rosen A, Machamer CE. 2005. Caspase-resistant Golgin-160 disrupts apoptosis induced by secretory pathway stress and ligation of death receptors. Mol Biol Cell 16: 3019-3027.

Mancini M, Machamer CE, Roy S, Nicholson DW, Thornberry NA, Casciola-Rosen LA, Rosen A. 2000. Caspase-2 is localized at the Golgi complex and cleaves golgin-160 during apoptosis. J Cell Biol 149: 603-612.

Martin M, Iyadurai SJ, Gassman A, Gindhart JG Jr, Hays TS, Saxton WM. 1999. Cytoplasmic dynein, the dynactin complex, and kinesin are interdependent and essential for fast axonal transport. Mol Biol Cell 10: 3717-3728.

Matanis T, Akhmanova A, Wulf P, Del Nery E, Weide T, Stepanova T, Galjart N, Grosveld F, Goud B, De Zeeuw CI, et al. 2002. Bicaudal-D regulates COPI-independent Golgi-ER transport by recruiting the dynein-dynactin motor complex. Nat Cell Biol 4: 986-992.

Miller PM, Folkmann AW, Maia AR, Efimova N, Efimov A, Kaverina I. 2009. Golgi-derived CLASP-dependent microtubules control Golgi organization and polarized trafficking in motile cells. Nat Cell Biol 11: 1069-1080.

Moreno RD, Schatten G, Ramalho-Santos J. 2002. Golgi apparatus dynamics during mouse oocyte in vitro maturation: effect of the membrane trafficking inhibitor brefeldin A. Biol Reprod 66: 1259-1266.

Mukherjee S, Shields D. 2009. Nuclear import is required for the pro-apoptotic function of the Golgi protein p115. J Biol Chem 284: 1709-1717.

Mukherjee S, Chiu R, Leung SM, Shields D. 2007. Fragmentation of the Golgi apparatus: an early apoptotic event independent of the cytoskeleton. Traffic 8: 369-378,

Muresan V, Stankewich MC, Steffen W, Morrow JS, Holzbaur EL, Schnapp BJ. 2001. Dynactin-dependent, dynein-driven vesicle transport in the absence of membrane proteins: a role for spectrin and acidic phospholipids. Mol Cell 7: 173-183.

Nebenfuhr A, Frohlick JA, Staehelin LA. 2000. Redistribution of Golgi stacks and other organelles during mitosis and cytokinesis in plant cells. Plant Physiol 124: 135-151.

Niclas J, Allan VJ, Vale RD. 1996. Cell cycle regulation of dynein association with membranes modulates microtubule-based organelle transport. J Cell Biol 133: 585-593.

Nikulina K, Patel-King RS, Takebe S, Pfister KK, King SM. 2004. The Roadblock light chains are ubiquitous components of cytoplasmic dynein that form homo- and heterodimers. Cell Motil Cytoskeleton 57: 233-245.

Nozawa K, Casiano CA, Hamel JC, Molinaro C, Fritzler MJ, Chan EK. 2002. Fragmentation of Golgi complex and
Golgi autoantigens during apoptosis and necrosis. Arthritis Res 4: R3.

Palazzo AF, Joseph HL, Chen YJ, Dujardin DL, Alberts AS, Pfister KK, Vallee RB, Gundersen GG. 2001. Cdc42, dynein, and dynactin regulate MTOC reorientation independent of Rho-regulated microtubule stabilization. Curr Biol 11: 1536-1541.

Palmer KJ, Hughes H, Stephens DJ. 2009. Specificity of cytoplasmic dynein subunits in discrete membranetrafficking steps. Mol Biol Cell 20: 2885-2899.

Papoulas O, Hays TS, Sisson JC. 2005. The golgin Lava lamp mediates dynein-based Golgi movements during Drosophila cellularization. Nat Cell Biol 7: 612-618.

Payne C, Schatten G. 2003. Golgi dynamics during meiosis are distinct from mitosis and are coupled to endoplasmic reticulum dynamics until fertilization. Dev Biol 264: 50-63.

Pazour GJ, Dickert BL, Witman GB. 1999. The DHC1b (DHC2) isoform of cytoplasmic dynein is required for flagellar assembly. J Cell Biol 144: 473-481.

Preisinger C, Short B, De Corte V, Bruyneel E, Haas A, Kopajtich R, Gettemans J, Barr FA. 2004. YSK1 is activated by the Golgi matrix protein GM130 and plays a role in cell migration through its substrate 14-3-35. J Cell Biol 164: 1009-1020.

Preuss D, Mulholland J, Franzusoff A, Segev N, Botstein D. 1992. Characterization of the Saccharomyces Golgi complex through the cell cycle by immunoelectron microscopy. Mol Biol Cell 3: 789-803.

Prigozhina NL, Waterman-Storer CM. 2004. Protein kinase $\mathrm{D}$-mediated anterograde membrane trafficking is required for fibroblast motility. Curr Biol 14: 88-98.

Ralston E. 1993. Changes in architecture of the Golgi complex and other subcellular organelles during myogenesis. J Cell Biol 120: 399-409.

Rios RM, Sanchis A, Tassin AM, Fedriani C, Bornens M. 2004. GMAP-210 recruits $\gamma$-tubulin complexes to cisGolgi membranes and is required for Golgi ribbon formation. Cell 118: 323-335.

Roghi C, Allan VJ. 1999. Dynamic association of cytoplasmic dynein heavy chain 1a with the Golgi apparatus and intermediate compartment. J Cell Sci 112: 4673-4685.

Sahlender DA, Roberts RC, Arden SD, Spudich G, Taylor MJ, Luzio JP, Kendrick-Jones J, Buss F. 2005. Optineurin links myosin VI to the Golgi complex and is involved in Golgi organization and exocytosis. J Cell Biol 169: 285-295.

Schatten G. 1994. The centrosome and its mode of inheritance: The reduction of the centrosome during gametogenesis and its restoration during fertilization. Dev Biol 165: 299-335.

Schmoranzer J, Kreitzer G, Simon SM. 2003. Migrating fibroblasts perform polarized, microtubule-dependent exocytosis towards the leading edge. J Cell Sci 116: 4513-4519.

Schroer TA. 2004. Dynactin. Annu Rev Cell Dev Biol 20: 759-779.

Schroer TA, Steuer ER, Sheetz MP. 1989. Cytoplasmic dynein is a minus end-directed motor for membranous organelles. Cell 56: 937-946. 
Sisson JC, Field C, Ventura R, Royou A, Sullivan W. 2000 Lava lamp, a novel peripheral golgi protein, is required for Drosophila melanogaster cellularization. J Cell Biol 151: 905-918.

Stanley H, Botas J, Malhotra V. 1997. The mechanism of Golgi segregation during mitosis is cell type-specific. Proc Natl Acad Sci 94: 14467-14470.

Starr DA, Williams BC, Hays TS, Goldberg ML. 1998. ZW10 helps recruit dynactin and dynein to the kinetochore. J Cell Biol 142: 763-774.

Stinchcombe JC, Majorovits E, Bossi G, Fuller S, Griffiths GM. 2006. Centrosome polarization delivers secretory granules to the immunological synapse. Nature 443: 462-465.

Tai AW, Chuang JZ, Bode C, Wolfrum U, Sung CH. 1999. Rhodopsin's carboxy-terminal cytoplasmic tail acts as a membrane receptor for cytoplasmic dynein by binding to the dynein light chain Tctex-1. Cell 97: 877-887.

Vaisberg EA, Grissom PM, McIntosh JR. 1996. Mammalian cells express three distinct dynein heavy chains that are localized to different cytoplasmic organelles. J Cell Biol 133: $831-842$.

Vale RD. 2003. The molecular motor toolbox for intracellular transport. Cell 112: 467-480.

Varma D, Dujardin DL, Stehman SA, Vallee RB. 2006. Role of the kinetochore/cell cycle checkpoint protein ZW10 in interphase cytoplasmic dynein function. J Cell Biol 172: 655-662.

Vaughan KT, Vallee RB. 1995. Cytoplasmic dynein binds dynactin through a direct interaction between the intermediate chains and p150Glued. J Cell Biol 131: 15071516.

Vaughan PS, Leszyk JD, Vaughan KT. 2001. Cytoplasmic dynein intermediate chain phosphorylation regulates binding to dynactin. J Biol Chem 276: 26171-26179.

Vaughan PS, Miura P, Henderson M, Byrne B, Vaughan KT. 2002. A role for regulated binding of p150(Glued) to microtubule plus ends in organelle transport. J Cell Biol 158: $305-319$.

Walenta JH, Didier AJ, Liu X, Kramer H. 2001. The Golgi-associated hook3 protein is a member of a novel family of microtubule-binding proteins. J Cell Biol 152: 923-934.

Waterman-Storer CM, Karki S, Holzbaur EL. 1995. The p150Glued component of the dynactin complex binds to both microtubules and the actin-related protein centractin (Arp-1). Proc Natl Acad Sci 92: 1634-1638.

Watson P, Stephens DJ. 2006. Microtubule plus-end loading of p150(Glued) is mediated by EB1 and CLIP-170 but is not required for intracellular membrane traffic in mammalian cells. J Cell Sci 119: 2758-2767.

Watson P, Forster R, Palmer KJ, Pepperkok R, Stephens DJ. 2005. Coupling of ER exit to microtubules through direct interaction of COPII with dynactin. Nat Cell Biol 7: 48-55.

Welte MA. 2004. Bidirectional transport along microtubules. Curr Biol 14: R525-537.

Whyte J, Bader JR, Tauhata SB, Raycroft M, Hornick J, Pfister KK, Lane WS, Chan GK, Hinchcliffe EH, Vaughan PS, et al. 2008. Phosphorylation regulates targeting of cytoplasmic dynein to kinetochores during mitosis. J Cell Biol 183: 819-834.

Xu Y, Takeda S, Nakata T, Noda Y, Tanaka Y, Hirokawa N. 2002. Role of KIFC3 motor protein in Golgi positioning and integration. J Cell Biol 158: 293-303.

Yadav S, Puri S, Linstedt AD. 2009. A primary role for Golgi positioning in directed secretion, cell polarity, and wound healing. Mol Biol Cell 20: 1728-1736.

Ye B, Zhang Y, Song W, Younger SH, Jan LY, Jan YN. 2007. Growing dendrites and axons differ in their reliance on the secretory pathway. Cell 130: 717-729.

Zmuda JF, Rivas RJ. 1998. The Golgi apparatus and the centrosome are localized to the sites of newly emerging axons in cerebellar granule neurons in vitro. Cell Motil Cytoskeleton 41: 18-38. 


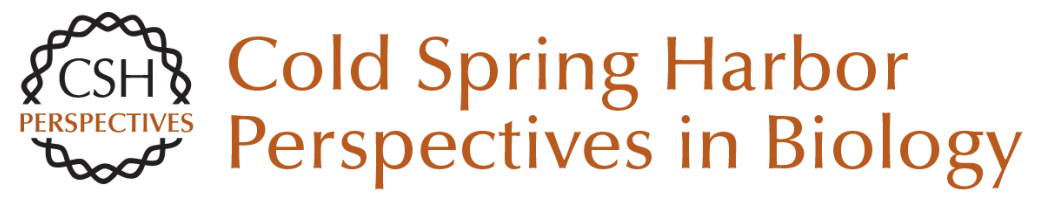

\section{Golgi Positioning}

Smita Yadav and Adam D. Linstedt

Cold Spring Harb Perspect Biol 2011; doi: 10.1101/cshperspect.a005322 originally published online April 6, 2011

\section{Subject Collection The Golgi}

Structure of Golgi Transport Proteins

Daniel Kümmel and Karin M. Reinisch

\section{Golgi Biogenesis}

Yanzhuang Wang and Joachim Seemann

Golgi Glycosylation and Human Inherited

Diseases

Hudson H. Freeze and Bobby G. Ng

Models for Golgi Traffic: A Critical Assessment Benjamin S. Glick and Alberto Luini

\section{Architecture of the Mammalian Golgi} Judith Klumperman

Evolution and Diversity of the Golgi Mary J. Klute, Paul Melançon and Joel B. Dacks

Evolutionary Forces Shaping the Golgi

Glycosylation Machinery: Why Cell Surface

Glycans Are Universal to Living Cells Ajit Varki

Golgi Positioning

Smita Yadav and Adam D. Linstedt
Golgi and Related Vesicle Proteomics: Simplify to Identify Joan Gannon, John J.M. Bergeron and Tommy Nilsson

Organization of SNAREs within the Golgi Stack Jörg Malsam and Thomas H. Söllner

Golgi during Development Weimin Zhong

Entry and Exit Mechanisms at the cis-Face of the Golgi Complex Andrés Lorente-Rodríguez and Charles Barlowe

COPI Budding within the Golgi Stack Vincent Popoff, Frank Adolf, Britta Brügger, et al.

Mechanisms of Protein Retention in the Golgi David K. Banfield

The Golgin Coiled-Coil Proteins of the Golgi

Apparatus Sean Munro

Signaling at the Golgi Peter Mayinger

For additional articles in this collection, see http://cshperspectives.cshlp.org/cgi/collection/

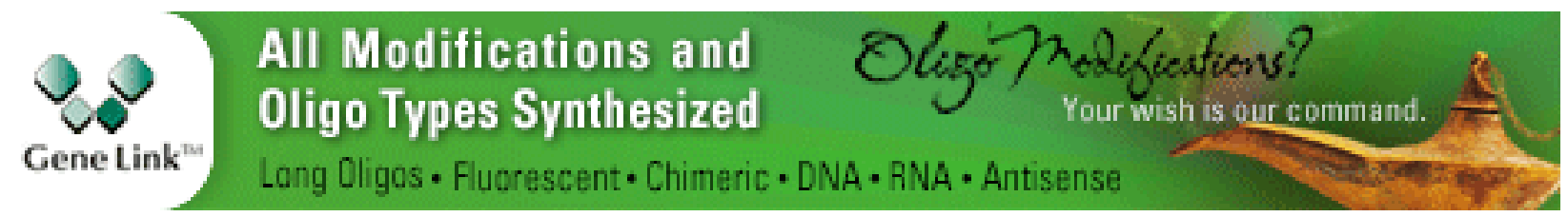

Copyright @ 2011 Cold Spring Harbor Laboratory Press; all rights reserved 